\title{
PENGEMBANGAN MEDIA GAME DIGITAL EDUKATIF UNTUK PEMBELAJARAN MENULIS LAPORAN PERJALANAN SISWA SEKOLAH MENENGAH PERTAMA
}

\author{
Anggia Suci Pratiwi ${ }^{1)}$, Tadkiroatun Musfiroh ${ }^{2)}$ \\ Program Studi Linguistik Terapan PPs UNY ${ }^{1)}$, Universitas Negeri Yogyakarta ${ }^{2)}$ \\ gia_maniez@yahoo.com ${ }^{1)}$, itadzuny@yahoo.co.id ${ }^{2)}$
}

\begin{abstract}
Abstrak
Penelitian ini bertujuan untuk mengembangkan media game digital edukatif yang efektif untuk pembelajaran menulis laporan perjalanan siswa Sekolah Menengah Pertama (SMP). Penelitian ini merupakan penelitian R\&D melalui tahapan analisis kebutuhan, pembuatan desain game, validasi produk, dan uji coba lapangan. Media game digital edukatif yang dikembangkan ini layak digunakan untuk pembelajaran menulis laporan perjalanan siswa SMP berdasarkan hasil validasi produk oleh ahli materi dengan hasil rata-rata yaitu 4,67 termasuk dalam kategori sangat baik, sedangkan validasi ahli media dengan hasil rata-rata 4,21 termasuk dalam kategori baik. Berdasarkan uji keefektifan menggunakan uji-t pada saat uji coba lapangan menunjukkan bahwa nilai t hitung $(4,543)>t$ tabel (30;0,05) adalah $(1,697)$. Oleh karena itu, media game digital edukatif yang telah dikembangkan efektif digunakan untuk pembelajaran menulis laporan perjalanan siswa SMP.
\end{abstract}

Kata kunci: pengembangan media, game digital edukatif, menulis laporan perjalanan.

\section{DEVELOPING EDUCATIVE DIGITAL GAME MEDIA \\ FOR THE TEACHING OF WRITING JOURNEY REPORTS TO JUNIOR HIGH SCHOOL STUDENTS}

\begin{abstract}
The research was aimed at developing effective educative digital game media for the learning of writing journey reports for junior high school (SMP) students. The research was an $R \& D$ research consisting of five steps, namely needs analyses, developing game design, product validation, and fiels testing. The product validation by material experts shows that the educative digital game media for teaching writing journey reports to junior high school students are in a very good category with the average score of 4,67. The product validation by media experts shows that the media are in a good category with the average score of 4,21. Therefore, educative digital game media are valid to be used in the teaching writing journey reports to junior high school students. The results of effectiveness testing using $t$-test shows $t$ count $(4,543)>t$ tabel ${ }_{(30 ; 0,05)}$ adalah $(1,697)$. It means that the developed educative digital game media are effective to be used in teaching of writing journey reports to junior high school students.
\end{abstract}

Keywords: Developing media, the educative digital game media, writing journey reports. 


\section{PENDAHULUAN}

Dewasa ini kebutuhan terhadap media pembelajaran semakin meningkat. Menurut Sadiman (2010, p.10), "media pembelajaran tidak lagi hanya dipandang sebagai alat bantu bagi guru dalam mengajar, tetapi sebagai alat penyalur pesan". Berdasarkan fungsi media pembelajaran tersebut, media tidak hanya dapat digunakan oleh guru, tetapi lebih penting lagi dapat digunakan oleh siswa. Oleh karena itu, media pembelajaran dapat mewakili guru dalam menyampaikan informasi secara teliti, jelas, dan menarik.

Sistem pembelajaran secara konvensional yang dulu dianggap paling efektif dan telah diterapkan dalam kegiatan belajar mengajar sehari-hari, sekarang sudah tidak sanggup mengikuti perkembangan zaman. Albert Shanker (Kepala Persatuan Guru New York City dan Ketua Serikat Guru Nasional) mengungkapkan bahwa hanya 20 sampai 25 persen dari siswa saat di sekolah dapat belajar secara efektif dengan pengajaran tradisional (Prensky, 2001, p.7). Dibutuhkan sebuah media pembelajaran yang mampu memenuhi segala tuntutan dan kebutuhan pembelajaran saat ini.

Banyak cara untuk mengikuti perkembangan kebutuhan media pada dunia pendidikan, yaitu pembelajaran dengan menggunakan teknologi sebagai sarana penyampai materi. Penggunaan teknologi sebagai media pembelajaran, salah satunya yaitu media game. Penggunaan game dalam pembelajaran lebih dikenal dengan Pembelajaran Berbasis Permainan (Game Based Learning).

Sampai akhir abad 19 game diasosiasikan dengan hiburan, tetapi dengan pengaruh John Dewey pada tahun 1944, game mulai memegang peranan dalam teknologi pengajaran. Game diperkenalkan di sekolah menjadi sesuatu yang lebih dari sekadar hiburan.

Pembelajaran berbasis game atau game based learning (GBL) seperti yang dikemukan oleh Torrente (2009, p.10) adalah "the use of digital games with serious goals (i.e. educational ob-jectives), as tools that support learning processes in a significant way. It is also known as educational gaming." Jadi pembelajaran berbasis game digital yaitu penggunaan game digital dengan tujuan yang serius (yaitu tujuan pendidikan), sebagai alat yang mendukung proses pembelajaran secara signifikan. Game untuk pembelajaran juga harus dikemas secara menarik dan interaktif agar siswa termotivasi oleh permainan dalam game tersebut dan efektif digunakan dalam pembelajaran

Guru harus hati-hati dalam mengadopsi dan menggunakan game karena tujuan awal game dibuat adalah untuk hiburan tetapi sekarang game digunakan untuk pendidikan, sehingga game harus memenuhi kriteria-kriteria yang telah ditetapkan dalam tujuan pembelajaran. Seperti yang diungkapkan oleh Van Eck (2006, p.18), "Games are effective not because of what they are, but because of what they embody and what learners are doing as they play a game." Oleh karena itu, game edukatif harus memberikan dampak positif bagi pembelajaran.

Game edukatif dibuat untuk pembelajaran mengenai subjek tertentu, perluasan konsep, pengembangan penguatan, pemahaman peristiwa sejarah atau budaya, serta penguasaan keterampilan tertentu. Game edukatif ini juga memberikan kesempatan bagi guru untuk memperkenalkan elemen game dalam lingkungan pembelajaran. Game efektif dalam pembelajaran karena sesuai dengan konteks yang berkaitan dengan lingkungan siswa dan dipraktekkan sesuai dengan konteks tersebut. Seperti yang diungkapkan oleh Van Eck (2006, p.19):

Games are effective partly because the learning takes place within a meaningful (to the game) context. What you must learn is directly related to the environment in which you learn and demonstrate it; thus, the learning is not only relevant but applied and practiced within that context. Learning that occurs in meaningful and relevant contexts is more effective than learning that occurs outside of those contexts, as is the case with most formal instruction.

Untuk memahami konteks tersebut, maka dibutuhkan imajinasi atau fantasi siswa untuk membayangkan bahwa siswa tersebut sedang menyelesaikan suatu kegiatan dalam konteks yang sebenarnya, namun siswa tidak benar-benar hadir. Hal ini sejalan dengan yang dikemukakan oleh Rieber (1996, p.8), "fantasy is used to encourage learners to imagine that they are completing the activity in a context in which they are really not present".

Ciri-ciri pembelajaran berbasis game yang dikemukakan oleh Teed (2010) adalah sebagai berikut, (a) pembelajaran berbasis game menggunakan latihan kompetitif. Game yang baik akan memberikan tantangan yang terus menerus. Tantangan yang satu akan mengarah pada tantangan yang lainnya. Setiap tantangan harus 
memenuhi beberapa jenis tujuan pembelajaran, misalnya tantangan menjawab pertanyaan, mengidentifikasi sampel atau menyelesaikan pengukuran atau tantangan permainan yang lebih sulit, dan (b) game biasanya memiliki elemen fantasi yang melibatkan permainannya dalam kegiatan belajar melalui sebuah alur cerita (storyline). Story line yang baik dapat menghidupkan kompetisi.

Game yang baik bersifat fleksibel, yaitu ada banyak cara untuk mencapai tujuan bermain. Penghargaan atas keberhasilan bermain perlu disediakan pada pembelajaran berbasis game, hal ini bertujuan agar siswa tidak bermain game hanya untuk menang, tetapi untuk terus bermain.

Game yang baik yaitu game yang menggabungkan antara kesenangan dan kenyataan. Menurut Sandford \& Williamson (2005, p.3), game merupakan sarana pembelajaran yang ideal. Karakterisitik game edukatif yang pertama, yaitu game harus bersifat menantang dan mendukung siswa untuk melakukan pendekatan, penyelidikan, dan penyelesaian masalah yang semakin kompleks, dengan demikian siswa dapat belajar cara mengatasi masalah dalam konteks yang serupa pada kehidupan nyara. Kedua, game edukatif dapat menyedikan kapasitas bagi siswa dalam mencoba alternatif pembelajaran dalam konteks tertentu hingga siswa dapat mengerti cara memainkan sistem dengan konsekuensi tertentu.

Game digital edukatif sudah sejak lama dibuat, namun belum dioptimalkan sebagai media pembelajaran. Perkembangan game digital edukatif yang sudah ada masih kalah dengan game digital yang nonedukatif. Saat pertama kali diperkenalkan, game digital edukatif masih kurang diminati oleh masyarakat, khususnya siswa. Hal ini dikarenakan game digital edukatif tersebut kurang menantang dan kurang menghibur. Oleh karena itu, perlu adanya pengembangan terhadap media game digital edukatif tersebut menjadi lebih menarik, sehingga siswa bisa bermain game digital tanpa melupakan kompetensi yang harus dikuasai.

Terdapat banyak kelebihan dari pembelajaran menggunakan media game digital ini, yaitu mampu membuat para siswa menjadi tidak mudah bosan dan materi pelajaran menjadi lebih mudah tersampaikan. Selain itu, media game digital mampu mengefisiensikan waktu yang dibutuhkan untuk menyelesaikan suatu kompetensi karena dengan game digital, para siswa lebih cepat menangkap pelajaran. Salah satu kompetensi yang harus dikuasai oleh siswa SMP yaitu kompetensi menulis.

Di dalam kegiatan menulis, seseorang dapat menyampaikan gagasan, ide, konsep, dan keinginannya. Menulis juga dapat digunakan untuk merekam peristiwa, melaporkan kejadian, meyakinkan, dan mempengaruhi (provokatif) dalam bentuk tulisan. Dengan demikian kegiatan menulis dalam dunia pendidikan dapat berupa keterampilan membuat laporan, ikhtisar, menyusun makalah, dan hal-hal yang berkaitan dengan media yang dapat digunakan untuk menyampaikan gagasan, fakta, dan pendapatnya dalam ragam tulisan.

Permasalahannya saat ini adalah kompetensi menulis merupakan kompetensi yang sulit dikembangkan pada siswa SMP karena menulis menghendaki penguasaan dari berbagai unsur kebahasaan dan unsur di luar bahasa yang akan menjadi unsur karangan. Menurut Nurgiyantoro (2011, p.422), "unsur bahasa maupun unsur isi pesan harus terjalin sedemikian rupa, sehingga menghasilkan karangan yang runtut, padu, dan berisi". Selain itu, dalam pembelajaran menulis, siswa diwajibkan untuk menuangkan ide, gagasan, dan imajinasi dalam bentuk tulisan.

Kesulitan yang dihadapi oleh siswa yaitu dalam menuangkan gagasan awal. Hal ini dikarenakan siswa dituntut untuk membayangkan sesuatu yang tidak nyata. Pembelajaran menulis khususnya menulis laporan perjalanan, seringkali dianggap sebagai pembelajaran yang tidak penting dan membosankan. Namun sebenarnya, menulis laporan perjalanan merupakan bagian dari reportase, catatan harian, dan bagian dari penyediaan informasi bagi orang lain yang hendak melakukan perjalanan. Seperti yang diungkapkan Fauzi (2012) bahwa laporan perjalanan disusun sebagai suatu pertanggungjawaban setelah melakukan perjalanan.

Laporan perjalanan merupakan salah satu jenis laporan. Berdasarkan definisi laporan secara umum, maka laporan perjalanan adalah laporan yang ditulis sebagai bentuk reportase dari suatu perjalanan yang telah diselenggarakan untuk mengetahui keseluruhan pelaksanaan perjalanan tersebut.

Laporan perjalanan berisi fakta-fakta mengenai semua hal yang berhubungan dengan kegiatan dalam perjalanan. Fakta-fakta yang dituliskan dalam laporan merupakan gambaran objektif dari semua hal yang telah dilakukan baik saat persiapan, saat perjalanan atau kunjungan objek, maupun saat perjalanan pulang. 
Dengan demikian, pembaca akan memperoleh gambaran yang jelas tentang perjalanan tersebut.

Dalam menulis laporan perjalanan siswa dituntut untuk melibatkan diri dalam tulisan dengan mengungkapkan pengalaman ketika melakukan perjalanan, tentu saja siswa tersebut tidak sekadar menceritakan pengalamannya, tetapi juga mendeskripsikan tempat dan aktivitasnya. Dengan demikian, pembaca selain turut merasakan pengalaman penulis, juga mendapat informasi tentang lokasi yang menjadi tujuan perjalanan serta peristiwa yang menyertainya. Hal ini yang menjadi kendala bagi siswa dalam menulis laporan perjalanan. Oleh karena itu, diperlukan media yang mampu memberikan gambaran secara visual. Salah satu media yang dapat memberikan gambaran secara visual yaitu media game digital.

Media game digital edukatif diharapkan dapat membantu dalam pembelajaran menulis laporan perjalanan. Oleh karena itu, metode penelitian yang digunakan yaitu metode penelitian dan pengembangan (Research and Development) karena penelitian ini akan menghasilkan sebuah produk berupa media game edukatif untuk pembelajaran menulis laporan perjalanan.

\section{METODE}

Jenis penelitian ini merupakan penelitian pengembangan (Research and Development). Menurut Borg \& Gall (1983, p.772), model penelitian dan pengembangan adalah "a process used develop and validate educational product" yaitu penelitian yang berorientasi pada pengem- bangan dan validasi produk-produk pembelajaran.

\section{Jenis Data}

Data yang diperoleh dalam penelitian ini merupakan data kualitatif dan data kuantitatif. Data kualitatif yaitu berupa data yang diperoleh berdasarkan hasil validasi ahli media dan ahli materi, guru, siswa, dan teman sejawat yang berupa komentar, masukan/saran untuk mengetahui tingkat kelayakan produk media game edukatif. Data kuantitatif yaitu berdasarkan data yang diperoleh dari skor tanggapan para ahli dan siswa untuk mengukur kelayakan media, serta skor pretest dan posttest untuk mengetahui keefektifan media game edukatif yang dikembangkan.

\section{Waktu dan Tempat Penelitian}

Penelitian ini dilakukan dari bulan Februari sampai April 2013 di SMP Negeri 6 Yogyakarta.

\section{Subjek Penelitian}

Subjek dalam penelitian ini adalah siswa kelas VIII-G. Subjek penelitian ditentukan dengan melakukan pretest terlebih dahulu.

\section{Prosedur}

Prosedur pengembangan pada penelitian dan pengembangan media game edukatif untuk pembelajaran menulis laporan perjalanan dapat dilihat pada bagan berikut. 


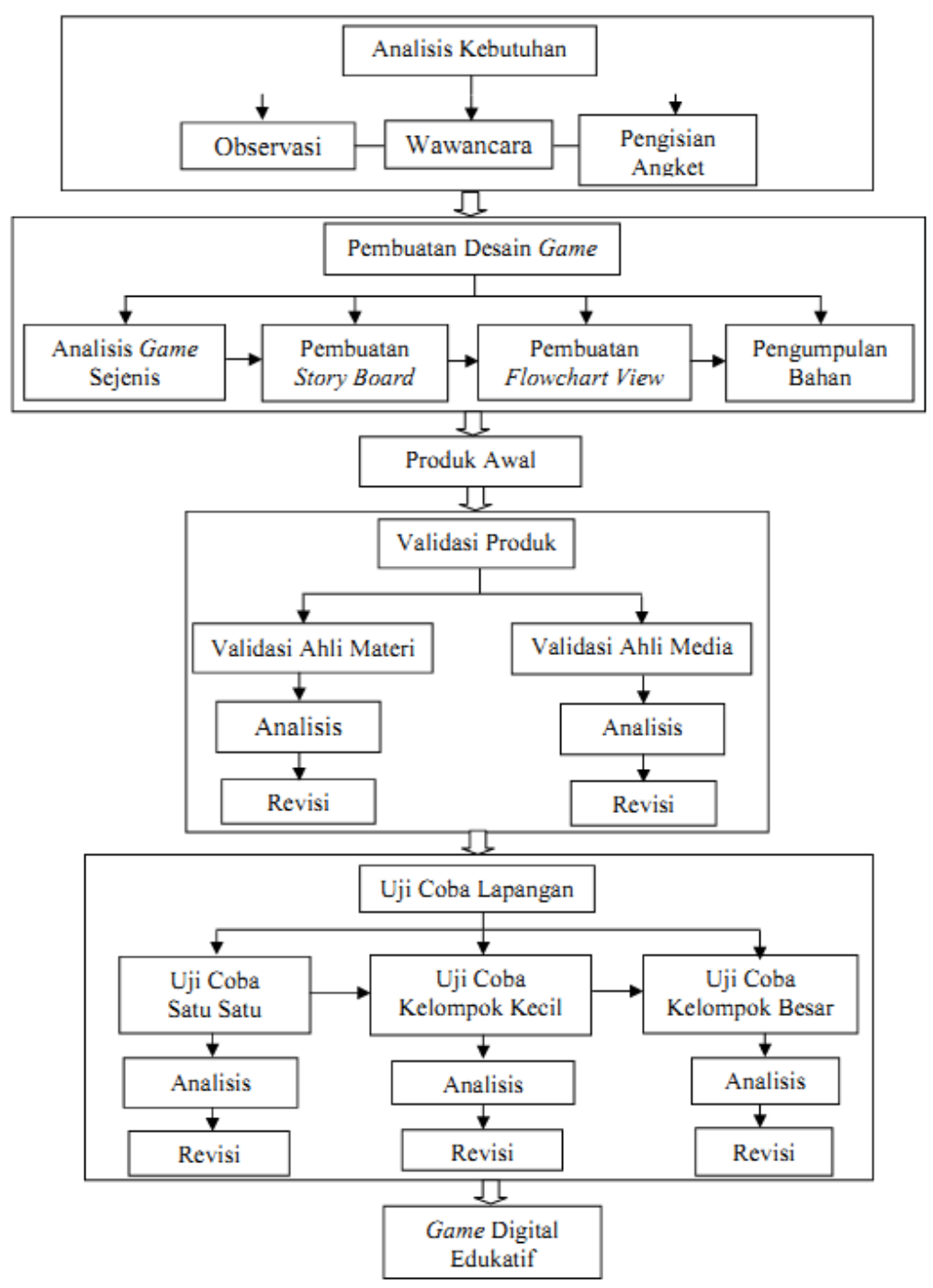

Gambar 1. Prosedur Pengembangan Media Game Edukatif untuk Menulis Laporan Perjalanan

\section{Data, Intrumen, dan Teknik Pengumpulan Data}

Data dalam penelitian ini yaitu data kualitatif dan data kuantitatif. Data kualitatif yaitu berupa data yang diperoleh berdasarkan hasil validasi ahli media dan ahli materi, guru, siswa, dan teman sejawat yang berupa komentar, masukan/saran untuk mengetahui tingkat kelayakan produk media game edukatif. Data kuantitatif yaitu berdasarkan data yang diperoleh dari skor tanggapan para ahli dan siswa untuk mengukur kelayakan media, serta skor pretest dan postest untuk mengetahui keefektifan media game edukatif yang dikembangkan.

Instrumen penelitian yang digunakan dalam penelitian pengembangan ini yaitu lembar observasi sebagai sarana untuk mengungkap kekurangan media atau pembelajaran yang telah dilakukan sebelumnya, lembar wawancara dila- kukan untuk mendapatkan masukan berupa saran dan kritik dari ahli materi, ahli media, guru, maupun siswa, angket, yaitu berupa lembar validasi ahli materi dan ahli media, angket siswa untuk uji coba satu-satu, serta angket siswa kelompok kecil, lembar validasi ahli materi digunakan untuk mengukur kualitas pembelajaran dan kebenaran isi. Lembar validasi ahli media digunakan untuk mengukur kualitas aspek tampilan dan pemprograman, sedangkan angket siswa untuk mengukur kualitas tampilan, pemprograman, dan pembelajaran. Tes yang diberikan pada siswa yaitu tes menulis laporan perjalanan berupa pretest dan posttest dengan menggunakan media game digital edukatif.

\section{Teknik Analisis Data}

Teknik analisis data dilakukan dengan cara deskriptif kualitatif dan deskriptif kuanti- 
tatif. Data hasil pengamatan, hasil wawancara, komentar dan saran dianalisis secara deskriptif kualitatif. Data berupa skor hasil validasi ahli dan siswa serta skor hasil pretest dan posttest dianalisis secara deskriptif kuantitatif.

Langkah-langkah yang digunakan untuk menentukan kriteria kelayakan produk yang telah dikembangkan, sebagai berikut.
Pertama, mengubah data yang diperoleh dari angket berupa tanggapan menjadi data interval sebagai berikut.

Sangat baik $=5 ;$ Baik $=4$; Cukup $=3$;

Kurang $=2$; dan Sangat kurang $=1$.

Tabel 1. Konversi Data Kuantitatif ke Data Kualitatif dengan Skala Lima

\begin{tabular}{ccc}
\hline \multicolumn{1}{c}{ Skor } & Perhitungan & \multirow{2}{*}{ Kriteria } \\
\hline$X>X_{\mathrm{i}}+1,80 S B_{\mathrm{i}}$ & $X>4,21$ & Sangat Baik \\
\hline $0,60 S B_{1}<X \leq X_{\mathrm{i}}+1,80 S B_{\mathrm{i}}$ & $3,40<X \leq 4,21$ & Baik \\
\hline $0,60 S B_{1}<X \leq X_{\mathrm{i}}+0,60 S B_{1}$ & $2,60<X \leq 3,40$ & Cukup \\
\hline $1,80 S B_{\mathrm{i}}<X \leq X_{\mathrm{i}}-0,60 S B_{\mathrm{i}}$ & $1,79<X \leq 2,60$ & Kurang \\
\hline$X \leq X_{\mathrm{i}}-1,80 S B_{\mathrm{i}}$ & $X \leq 1,79$ & Sangat Kurang \\
\hline
\end{tabular}

Sumber: Widyoko (2009, p.238)

Keterangan:

Rerata skor ideal $\left(X_{i}\right): \frac{1}{2}$ (Skor maksimal ideal + skor minimal ideal)

Simpangan baku skor ideal $\left(S B_{i}\right)$ : $\frac{1}{6}$ (Skor maksimal ideal - skor minimal ideal)

\section{X: Skor empiris}

Menghitung skor rata-rata dalam memberikan penilaian terhadap produk yang telah dikembangkan digunakan rumus :

$X_{i}=\frac{\sum X}{n}$

Keterangan :

$X_{i}=$ skor rata-rata

$\sum X=$ jumlah skor

$\mathrm{n}=$ jumlah responden

Dalam penelitian ini ditetapkan nilai kelayakan produk minimal dengan kategori 'cukup baik' berdasarkan hasil penilaian dari ahli media, ahli materi, maupun siswa. Jika hasil penilaian akhir (keseluruhan) pada aspek media dan aspek materi dengan nilai minimal 'cukup baik' oleh para ahli dan siswa, maka produk hasil pengembangan tersebut sudah dianggap layak digunakan sebagai media pembelajaran.

Teknik analisis data yang digunakan pada uji keefektifan media adalah Uji-t. Uji-t dimaksudkan untuk mengetahui signifikansi perbedaan kemampuan menulis laporan perjalanan siswa kelas VIII SMP Negeri 6 sebelum dan sesudah penggunaan media game digital edukatif.

Untuk mengetahui adanya perbedaan keefektifan antara hasil menulis laporan perjalanan sebelum dan sesudah penggunaan media game digital edukatif dirumuskan hipotesis sebagai berikut:
$H_{0} \quad$ media game digital edukatif kurang efektif digunakan untuk menulis laporan perjalanan siswa.

$H_{1} \quad$ media game digital edukatif efektif digunakan untuk menulis laporan perjalanan siswa.

$H_{0}$ diterima jika t hitung $<\mathrm{t}$ tabel; $\alpha=0,05$

\section{HASIL DAN PEMBAHASAN}

Hasil penelitian ini menyajikan data-data yang diperoleh dari analisis kebutuhan; pembuatan desain game; validasi ahli yaitu validasi ahli materi dan ahli media; dan uji coba lapangan yaitu uji coba satu-satu, uji coba kelompok kecil, dan uji coba kelompok besar untuk mengetahui keefektifan media game digital edukatif yang dikembangkan.

\section{Analisis Kebutuhan}

Analisis kebutuhan yang dilakukan dalam penelitian ini yaitu berupa observasi, wawancara dengan guru, dan pengisian angket siswa. Hasil observasi menyatakan bahwa dalam proses pembelajaran, guru menggunakan media berupa majalah yang di dalamnya terdapat contoh laporan perjalanan. Guru memerintahkan siswa untuk menulis laporan perjalanan berdasarkan pengalaman yang pernah dilalui siswa sesuai dengan contoh yang sudah ada. Guru tidak memberikan tema atau petunjuk lainnya untuk 
menulis laporan perjalanan. Siswa terlihat tidak terlalu antusias mengikuti pembelajaran bahasa Indonesia dan tidak tertarik terhadap media yang digunakan guru. Selain itu, berdasarkan hasil observasi dapat diketahui bahwa di SMP Negeri 6 Yogyakarta unit komputer memadai dan layak digunakan.

Berdasarkan hasil wawancara, guru kurang senang dengan siswa yang bermain game karena biasanya siswa suka lupa waktu, namun guru mendukung media game digital edukatif jika dapat meningkatkan kompetensi siswa. Jenis game digital yang sesuai untuk pembelajaran menurut guru yaitu yang dapat meningkatkan kompetensi, bukan hanya untuk senangsenang saja. Kriteria game yang layak dijadikan media pembelajaran menurut guru yaitu yang tidak mengandung unsur kekerasan, pornografi, dan hal-hal yang dapat merusak moral siswa.

Berdasarkan hasil angket siswa diketahui bahwa banyak siswa cukup kesulitan dalam menulis laporan perjalanan. Banyak siswa yang merasa kesulitan dalam menyusun kalimat yang kohesif dan koheren. Alasan siswa merasa kesulitan yaitu media pembelajaran yang monoton. Kebanyakan siswa menghabiskan lebih dari tiga puluh menit untuk menyelesaikan tugas menulis laporan perjalanan.

Rata-rata siswa bermain game pada platform bermain game selama 1-3 jam. Kebanyakan siswa pernah bermain game edukatif dan bermain pada platform desktop PC/software. Banyak siswa menyatakan tertarik untuk bermain game yang dipadukan dengan pembelajaran bahasa Indonesia.

Jenis game yang paling disukai yaitu role playing game (RPG). Banyak siswa menyatakan bahwa fitur yang paling menarik yaitu game play. Genre game yang paling menarik menurut siswa yaitu action.

\section{Pembuatan Desain Game}

Pembuatan desain game melalui tahapan analisis game sejenis, pembuatan story board, pembuatan flowchart view, dan pengumpulan bahan. Game sejenis yang dianalisis yaitu Game yang dianalisis adalah Arcuz: Behind The Dark, Plant Vs Zombie, Free Rice, dan Book Worm. Game-game ini dipilih karena memiliki unsur edukasi, game play yang unik, fitur yang menarik, dan dapat dimainkan oleh berbagai umur.

Tahapan analisis game sejenis ini dilakukan untuk mengetahui kelebihan dan kekurangan dari game-game edukatif lain. Kelebihan ini yang akan dijadikan dasar untuk pembuatan game digital edukatif, sedangkan kekurangannya ditinjau agar kekurangan tersebut dapat dilengkapi pada game ini. Setelah dilakukan analisis game sejenis, masuk pada tahap pembuatan story board. Story board dibuat sebagai pedoman dari pengembangan yang akan dilakukan. Story board ini berupa rangkaian gambar manual yang dibuat secara keseluruhan, sehingga menggambarkan suatu cerita.

Setelah story board selesai dibuat, kemudian dilanjutkan pada tahap selanjutnya yaitu pembuatan flowchart view. Tahapan-tahapan dalam game digital edukatif ini akan disajikan terlebih dahulu dalam flowchart view, agar alur game dapat terlihat dengan jelas. Setelah pembuatan flowchart view, kemudian dilakukan pengumpulan bahan berdasarkan hasil analisis game sejenis, story board, dan flowchart view.

Berdasarkan langkah analisis game sejenis, pembuatan story board, dan flowchart view ditentukan desain game dengan game play berupa mengalahkan musuh dan berhak menyelesaikan soal yang telah ditentukan. Fitur yang ditentukan berupa arena dan petunjuk, serta soal Elemen Multimedia berupa animasi, text, gambar, dan suara. Tujuan dan materi yaitu untuk membantu siswa dalam menulis laporan perjalanan. Platform media game digital edukatif dibuat pada desktop

Adapun story board media game digital ini yaitu cerita tentang seorang siswa bernama Satria beserta rombongan sekolah melakukan study tour. Satria dan teman-teman diberi tugas untuk menuliskan setiap apa yang dijumpai dalam perjalanan. Rombongan boleh berpencar, namun nanti harus berkumpul di lantai atas Borobudur untuk menyerahkan tugas. Tiap siswa diberi kertas untuk menulis. Informasi mengenai candi Borobudur diberikan pada saat guru memberikan petunjuk pada siswa.

Satria berpisah dari teman-teman dan melihat pencuri-pencuri patung yang tengah beraksi. Dia pun tidak tinggal diam, dia berusaha untuk mencegah dan melawan pencuri tersebut dengan menggunakan senjata seadanya. Jika Satria berhasil mengalahkan satu pencuri, dia berhak mendapatkan hadiah. Setelah semua pencuri beserta Bos di level pertama berhasil dikalahkan, Satria berhak mendapat petunjuk dan pertanyaan untuk menulis laporan perjalanan. Begitupun selanjutnya sampai pada tahap tiga game.

Adapun flowchart view game digital edukatif yaitu title page, menu, main, narasi, tahap 1, kolom isian penulisan kerangka laporan 
perjalanan berdasarkan urutan waktu, tahap 2, kolom isian penulisan kerangkan laporan perjalanan berdasarkan urutan tempat dan kegiatan, tahap 3, penulisan kerangka laporan perjalanan berdasarkan suasana yang terjadi dan hal yang mengesankan dan tidak mengesankan, narasi, ucapan selamat, tayangan hasil tulisan siswa, dan evaluasi guru.

Proses pengumpulan bahan pada tahap pembuatan desain game ini dimulai dengan mengumpulkan materi yang akan dijadikan sebagai petunjuk dan pertanyaan untuk membuat laporan perjalanan. Selain itu, pengumpulan informasi mengenai Borobudur juga sangat diperlukan untuk menambah wawasan siswa dalam membuat laporan. Setelah informasi dan materi terkumpul, langkah selanjutnya yaitu menentukan karakter dan tema yang tepat untuk membuat game digital edukatif yang sesuai dengan materi menulis laporan perjalanan. Penentuan karakter tokoh pada game ini hasil dari analisis karakter pada game digital edukatif lain yang serupa.

\section{Validasi Produk}

Validasi produk ini meliputi validasi ahli materi dan ahli media. Ahli materi yang ditunjuk untuk memvalidasi media game digital edukatif ini yaitu Prof. Suhardi (dosen Pascasarjana UNY, dosen Jurusan Pendidikan Bahasa dan Sastra Indonesia UNY, guru besar Fakultas Bahasa dan Seni Universitas Negeri Yogyakarta), sedangkan ahli media yaitu Herman Dwi Surjono, M.Sc., M.T., Ph.D (Dosen Pascasarjana UNY, Kaprodi Teknologi Pendidikan).

\section{Validasi Ahli Materi}

Validasi ahli materi dilakukan dengan tujuan untuk mendapatkan informasi, saran dan kritik untuk perbaikan kualitas media game digital edukatif. Pengembang mengharapkan produk media game digital edukatif untuk pembelajaran menulis laporan perjalanan ini berkualitas dari aspek format, aspek isi, aspek bahasa, dan aspek pembelajaran.

\section{Aspek Format}

Hasil validasi terhadap aspek format media game digital edukatif oleh ahli materi dapat dilihat pada tabel berikut ini.

Tabel 2. Aspek Format

\begin{tabular}{cc}
\hline Aspek & Kejelasan petunjuk pengerjaan \\
Format & Kesesuaian format game dengan mat \\
& \\
Hasil Rata-rata & \\
Berdasarkan tabel tersebut, ahli materi \\
memberi nilai 4 untuk kejelasan petunjuk pe- \\
ngerjaan, nilai 5 untuk kesesuaian format game \\
dengan materi menulis laporan perjalanan, dan \\
nilai 5 untuk kesesuaian isi pada media game \\
dengan konsep menulis laporan perjalanan. \\
Hasil rata-rata validasi ahli materi adalah $\mathbf{4 , 7 0}$ \\
untuk aspek format. Oleh karena itu, media
\end{tabular}

\section{Indikator}

ateri menulis laporan perjalanan 4,70

game

game digital edukatif yang dikembangkan ini mempunyai kriteria sangat baik untuk aspek format.

\section{Aspek Isi}

Hasil validasi terhadap aspek isi media game digital edukatif oleh ahli materi dapat dilihat pada tabel berikut ini.

Tabel 3. Aspek Isi

\begin{tabular}{clcc}
\hline Aspek & \multicolumn{1}{c}{ Indikator } & Penilaian \\
\hline Isi & Penyusunan prosedur pada media game & 5 \\
& Kesesuaian antara materi pada media pembelajaran dengan media game & 5 & 4 \\
& Peranan media game dalam mempermudah siswa menulis laporan perjalanan & 14 \\
Hasil Rata-rata & 3 & 4,60 & \\
& & &
\end{tabular}

Berdasarkan tabel tersebut, ahli materi memberi nilai 5 untuk penyusunan prosedur pada media game, nilai 5 untuk kesesuaian antara materi pada media pembelajaran dengan media game, dan nilai 4 peranan media game dalam mempermudah siswa menulis laporan perjalan- 
an. Hasil rata-rata validasi ahli materi adalah 4,60 untuk aspek isi. Oleh karena itu, media game digital edukatif yang dikembangkan ini mempunyai kriteria sangat baik untuk aspek isi.

\section{Aspek Bahasa}

Hasil penilaian terhadap aspek bahasa media game digital edukatif oleh ahli materi dapat dilihat pada tabel berikut ini.

Tabel 4. Aspek Bahasa

\begin{tabular}{cc}
\hline Aspek & Kebakuan bahasa yang digunakan \\
Bahasa & Kejelasan bahasa yang digunakan sehi \\
& Kemudahan siswa dalam memahami b \\
& Keefektifan kalimat yang digunakan \\
& Kelengkapan kalimat atau informasi y \\
Hasil Rata-rata & \\
Ahli materi memberi nilai 4 untuk keba- \\
kuan bahasa yang digunakan, nilai 4 untuk \\
kejelasan bahasa yang digunakan sehingga tidak \\
menimbulkan penafsiran ganda, nilai 5 untuk \\
kemudahan siswa dalam memahami bahasa \\
yang digunakan, nilai 4 untuk Keefektifan kali- \\
mat yang digunakan, dan nilai 5 untuk keleng- \\
kapan kalimat atau informasi yang dibutuhkan \\
oleh siswa. Hasil rata-rata validasi ahli materi
\end{tabular}
Penilaian

dikator
4

Tabel 5. Aspek Pembelajaran

\begin{tabular}{|c|c|c|}
\hline Aspek & Indikator & Penilaian \\
\hline \multirow[t]{7}{*}{ Pembelajaran } & Daya terima siswa & 5 \\
\hline & Pemberian umpan balik & 5 \\
\hline & Konsistensi dengan tujuan & 5 \\
\hline & Keruntutuan materi & 4 \\
\hline & Daya dukung program terhadap pembelajaran & 5 \\
\hline & Aspek motivasi & 5 \\
\hline & Interaksi selama pembelajaran & 5 \\
\hline \multirow[t]{2}{*}{ Hasil Rata-rata } & 7 & 34 \\
\hline & 4,86 & \\
\hline
\end{tabular}

Berdasarkan tabel tersebut, ahli materi memberi nilai 5 untuk daya terima siswa, nilai 5 untuk pemberian umpan balik, nilai 5 untuk konsistensi dengan tujuan, nilai 4 untuk keruntutan materi, nilai 5 untuk daya dukung program terhadap pembelajaran, nilai 5 untuk aspek motivasi, dan nilai 5 untuk interaksi selama pembelajaran. Hasil rata-rata validasi ahli materi adalah 4,86 untuk aspek pembelajaran. Oleh karena itu, media game digital edukatif yang dikembangkan ini mempunyai kriteria sangat baik untuk aspek pembelajaran.

Hasil rata-rata validasi ahli materi mencakup aspek format, isi, bahasa, dan pembelajaran yaitu 4,67 dengan kriteria sangat baik. Adapun revisi ahli materi terhadap media game digital edukatif media ini yaitu kata-kata asing di dalam game harus diindonesiakan dan ada beberapa adalah 4,40 untuk aspek bahasa. Oleh karena itu, media game digital edukatif yang dikembangkan ini mempunyai kriteria sangat baik untuk aspek bahasa.

\section{Aspek Pembelajaran}

Hasil validasi terhadap aspek pembelajaran media game digital edukatif oleh ahli materi dapat dilihat pada tabel berikut ini.

kata dan kalimat yang perlu diperbaiki karena tidak sesuai dengan EYD.

\section{Validasi Ahli Media}

Validasi ahli media dilakukan dengan tujuan untuk mendapatkan informasi, saran dan kritik untuk perbaikan kualitas media game digital edukatif. Pengembang mengharapkan produk media game digital edukatif untuk pembelajaran menulis laporan perjalanan ini berkualitas dari aspek tampilan dan pemrograman.

\section{Aspek Tampilan}

Hasil validasi terhadap aspek tampilan media game digital edukatif oleh ahli media dapat dilihat pada tabel berikut ini. 
Tabel 6. Aspek Tampilan

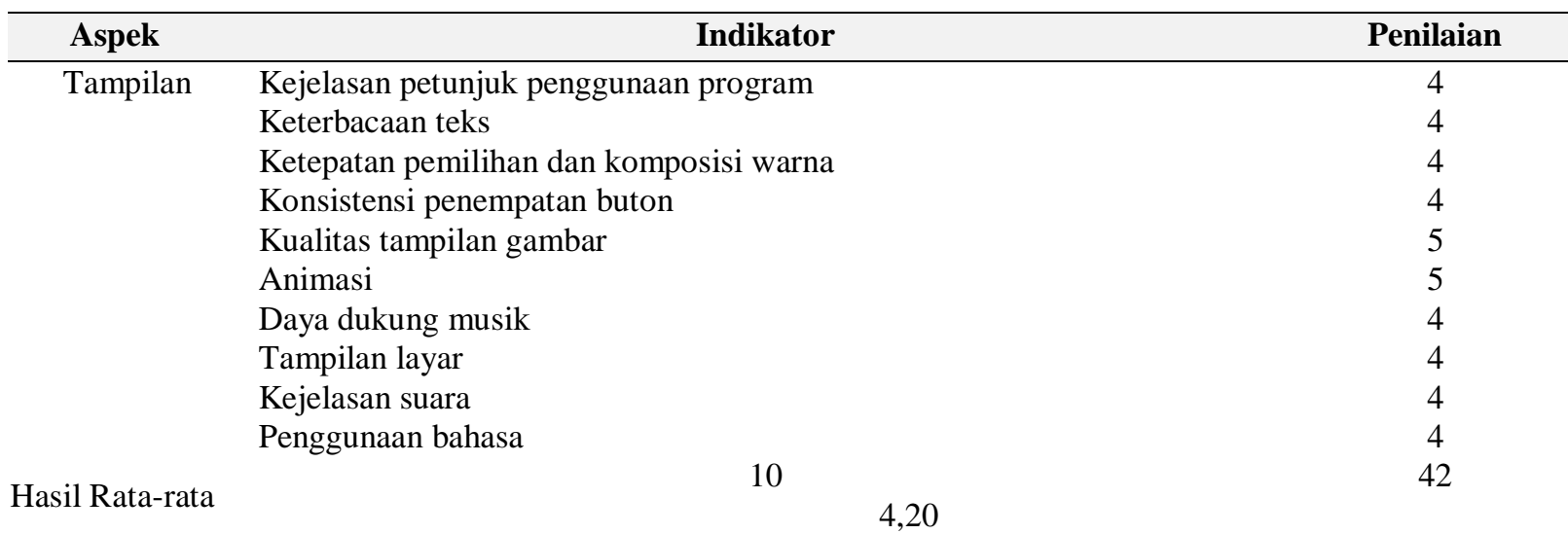

Berdasarkan tabel tersebut, penilaian oleh ahli media terhadap aspek tampilan, yaitu nilai 4 untuk kejelasan petunjuk penggunaan program, nilai 4 untuk keterbacaan teks, nilai 4 untuk ketepatan pemilihan dan komposisi warna, nilai 4 untuk konsistensi penempatan buton, nilai 5 kualitas tampilan gambar, nilai 5 untuk animasi, dan nilai 4 untuk daya dukung musik, nilai 4 untuk tampilan layar, dan nilai 4 untuk kejelasan suara, nilai 4 untuk penggunaan bahasa. Hasil rata-rata validasi ahli media adalah $\mathbf{4 , 2 0}$ untuk aspek tampilan. Oleh karena itu, media game digital edukatif yang dikembangkan ini mempunyai kriteria baik untuk aspek tampilan.

\section{Aspek Pemrograman}

Hasil validasi terhadap aspek pemrograman media game digital edukatif oleh ahli media dapat dilihat pada tabel berikut ini.

Tabel 7. Aspek Pemrograman

\begin{tabular}{clc}
\hline \multicolumn{1}{c}{ Aspek } & \multicolumn{1}{c}{ Indikator } & Penilaian \\
\hline Pemrograman & Kejelasan navigasi & 4 \\
& Konsistensi penggunaan tombol & 4 \\
& Kejelasan petunjuk & 4 \\
& Ketepatan pengaturan gambar & 4 \\
& Efisiensi penggunaan layar & 5 \\
& Efisiensi teks & 4 \\
& Antisipasi terhadap respon siswa & 4 \\
& Interaksi program & 5 \\
& Kecepatan program & 4 \\
& & 38 \\
& & 4,22 \\
\hline
\end{tabular}

Berdasarkan tabel tersebut, ahli media memberi nilai 4 untuk kejelasan navigasi, nilai 4 untuk konsistensi penggunaan tombol, nilai 4 untuk kejelasan petunjuk, nilai 4 untuk ketepatan pengaturan gambar, nilai 5 untuk efisiensi penggunaan layar, nilai 4 untuk efisiensi teks, nilai 4 untuk antisipasi terhadap respon siswa, nilai 5 untuk interaksi program, dan nilai 4 untuk kecepatan program. Hasil rata-rata validasi ahli media adalah $\mathbf{4 , 2 2}$ untuk aspek pemrograman. Oleh karena itu, media game digital edukatif yang dikembangkan ini mempunyai kriteria sangat baik untuk aspek pemrograman.
Hasil validasi ahli media termasuk dalam kategori baik, dilakukan sebanyak dua kali. Validasi pertama memperoleh hasil rata-rata $\mathbf{4 , 0 5}$, sedangkan validasi kedua yaitu 4,21. Adapun revisi dari ahli media yaitu berupa perlu ditambah title page, title page tanpa timer, full screen pada tampilan pertama, hilangkan animasi loading, perlu dicantumkan SK/KD, petunjuk help dapat diakses tiap halaman, dan icon nyawa seharusnya memakai angka.

\section{Uji Coba Lapangan}

Uji lapangan yang dilakukan pada penelitian ini yaitu uji coba satu-satu dengan melibatkan tiga orang siswa, uji coba kelompok kecil dengan melibatkan lima orang siswa, dan uji 
coba kelompok besar dengan melibatkan satu kelas yaitu sebanyak 31 siswa. Di akhir uji coba kelompok besar dilakukan uji keefektifan untuk mengetahui perbedaah hasil menulis laporan perjalanan antara sebelum dan sesudah menggunakan media game digital edukatif.

\section{Uji Coba Satu-Satu}

Hasil pengamatan selama pelaksanaan uji coba satu-satu, siswa sangat antusias dalam penggunaan media game digital edukatif ini. keseluruhan komentar bernada positif, namun siswa masih kesulitan dalam bermain. Dari uji coba satu-satu didapatkan masukan bahwa petunjuk bermain pada media game digital yang dikembangkan perlu diperjelas. Ketiga siswa ini tidak membaca petunjuk yang ada pada menu, langsung mengeklik tombol mulai dan langsung bermain. Oleh karena itu, perlu ditambah petunjuk pada setiap tahap pada game. Selain itu, backsound pada game tidak terlalu terdengar meskipun volume suara sudah penuh.

Pada kolom isian, perlu ditambahkan petunjuk mengenai langkah yang harus dikerjakan siswa. Ketiga siswa mengalami kebingungan ketika masuk pada kolom petunjuk dan pertanyaan untuk menulis laporan perjalanan. Soal dan petunjuk soal perlu diperbaiki lagi agar mudah dimengerti oleh siswa. Siswa belum dapat menuangkan ide karangan dengan baik pada kolom yang telah disediakan karena tidak ada petunjuk. Selain itu, rintangan pada tiap tahap game perlu diberi variasi karena siswa tidak mengalamai kesulitan dalam menyelesaikan setiap tahapnya.

Hasil penilaian siswa terhadap media game digital edukatif pada uji coba satu-satu dapat dilihat pada tabel berikut ini.

Tabel 8. Penilaian Uji Coba Satu-Satu

\begin{tabular}{cccc}
\hline Nama Siswa & Jumlah & Penilaian \\
\hline RM & 68 & 3,70 \\
GP & 72 & & 4,00 \\
RZH & 68 & 3,70 \\
Hasil Rata-rata & & 11,4 & \\
\hline
\end{tabular}

Berdasarkan tabel penilaian uji coba satusatu, siswa RM memberi penilaian 3,70 dengan kriteria baik, siswa GP memberi penilaian 4,00 dengan kriteria baik, dan siswa RZH memberi penilaian 3,70 dengan kriteria baik. Oleh karena itu, hasil uji coba satu-satu pada tiga orang siswa mendapat hasil rata-rata penilaian $\mathbf{3 , 8 0}$, sehingga mendapat kriteria baik.

\section{Uji Coba Kelompok Kecil}

Uji coba kelompok kecil pada penelitian pengembangan ini dilakukan pada lima orang siswa kelas VIII, sesuai dengan masukan dari guru. Siswa yang dipilih masing-masing mewakili kelompok yang memiliki prestasi belajar tinggi, sedang, dan rendah. Tahapan pada uji coba kelompok kecil sama dengan yang dilakukan pada uji coba satu-satu. Siswa difasilitasi komputer secara personal dalam penggunaan media. Siswa diminta untuk memberikan respon terhadap media yang sedang digunakan. Tanggapan dan informasi mengenai komentar dan saran dari siswa terhadap media diamati dan didokumentasikan oleh peneliti. Keseluruhan data hasil uji coba satu-satu dianalisis sebagai bahan masukan untuk revisi produk yang dikembangkan. Selain diminta tanggapan dan saran, siswa juga diminta untuk memberi penilaian terhadap media mengenai kualitas produk yang dikembangkan. Masukan dari uji coba kelompok kecil, yaitu perlu ditambahkan judul dan tujuan game, tembakan Satria kadang-kadang tidak berfungsi karena terjadi bugs, volume masih kurang tinggi, masih tidak terdengar jelas jika di ruangan yang luas.

Hasil penilaian siswa terhadap media game digital edukatif pada uji coba kelompok kecil dapat dilihat pada tabel berikut ini.

Tabel 9. Penilaian Uji Coba Kelompok Kecil

\begin{tabular}{ccc}
\hline Nama Siswa & Jumlah & Penilaian \\
\hline RM & 72 & 4,00 \\
GP & 78 & 4,33 \\
RZ & 72 & 4,00 \\
RY & 78 & 4,33 \\
AB & 80 & 4,44 \\
Hasil Rata-rata & \multicolumn{2}{c}{21,10} \\
\end{tabular}

Berdasarkan tabel tersebut, hasil uji coba kelompok kecil pada lima orang siswa mendapat hasil rata-rata 4,22. Siswa RM memberi penilaian 4,00 kriteria baik, GP memberi penilaian 4,33 kriteria sangat baik, RZ memberi penilaian 4,00 kriteria baik, RY memberi penilaian 4,33 kriteria sangat baik, $\mathrm{AB}$ memberi penilaian 4,44 kriteria sangat baik. Oleh karena itu, hasil uji kelompok kecil pada penelitian ini mendapat kriteria sangat baik.

\section{Uji Coba Kelompok Besar}

Pada saat uji coba kelompok besar ini, siswa terlihat antusias dan senang dalam bermain game. Hal ini dapat dilihat ketika siswa tertawa karena karakter yang dimainkan tidak 
mampu mengalahkan musuh. Siswa tidak mengalami kesulitan dalam hal petunjuk bermain. Siswa mengikuti setiap tahap dalam game. Petunjuk dan soal dalam game diikuti dengan baik, sehingga siswa tidak mengalami kesulitan dalam menuangkan ide karangan pada kolom yang telah disediakan.

Berdasarkan hasil uji coba kelompok besar, 13 siswa memberi penilaian dengan kriteria sangat baik, 16 siswa memberi penilaian dengan kriteria baik, dan 2 orang siswa dengan kriteria cukup. Siswa NPR memberi penilaian paling tinggi yaitu 3,88 dengan kriteria sangat baik, sedangkan siswa $\mathrm{AK}$ dan $\mathrm{AH}$ memberi penilaian paling rendah yaitu 3,00 dengan kriteria cukup. Oleh karena itu, hasil uji coba lapangan pada 31 siswa mendapat hasil rata-rata 3,99, sehingga media game digital edukatif ini mendapat kriteria baik.

Setelah dilakukan penilaian terhadap media game digital edukatif oleh siswa, dalam uji coba kelompok besar dilakukan uji keefektifan juga. Uji keefektifan ini dilakukan untuk mengetahui keefektifan media game edukatif dalam pembelajaran menulis laporan perjalanan. Uji keefektifan ini dimaksudkan untuk mengetahui signifikansi perbedaan kemampuan menulis laporan perjalanan siswa kelas VIII SMP Negeri 6 Yogyakarta antara sebelum (pretest) dan sesudah (posttest) diberi perlakuan berupa penggunaan media game digital edukatif.

Pretest dilakukan untuk mengetahui variansi siswa dan kemampuan awal siswa, sedangkan postestt diambil untuk mengetahui adanya peningkatan atau tidak dari media yang digunakan. Skor pretest diambil dari hasil menulis laporan perjalanan siswa sebelum diberi perlakuan, sedangkan posttest diambil dari hasil menulis laporan perjalanan setelah diberi perlakuan.

Berikut ini dilihat hasil menulis laporan perjalanan siswa, yaitu skor pretest dan postest dalam menulis laporan perjalanan

Tabel 10. Skor Pretest dan Posttest

\begin{tabular}{cccccc}
\hline \multicolumn{7}{c}{ Paired Samples Statistics } \\
\hline \multirow{2}{*}{ Pair 1 } & Mean & N & Std. Deviation & Std. Error Mean \\
& Skor Pretest & 79.45 & 31 & 3.668 & .659 \\
& Skor Posttest & 81.74 & 31 & 3.855 & .692 \\
\hline
\end{tabular}

Berdasarkan uji keefektifan pada saat uji coba kelompok besar dapat diketahui bahwa skor rata-rata pretest yaitu 79,45 dan skor posttest-nya yaitu 81,74 . Berdasarkan nilai ratarata skor pretest dan postest tersebut, ada per- bedaan yang signifikan pada hasil menulis laporan perjalanan pada siswa.

Pada tabel uji independent samples test di bawah ini dapat dilihat signifikansi peningkatan hasil menulis laporan perjalanan siswa.

Tabel 11. Uji Independent Samples Test

\begin{tabular}{|c|c|c|c|c|c|c|c|c|c|}
\hline \multicolumn{10}{|c|}{ Uji Independent Samples Test } \\
\hline & & \multicolumn{5}{|c|}{ Paired Differences } & \multirow{3}{*}{$\mathbf{T}$} & \multirow{3}{*}{\multicolumn{2}{|c|}{ Df $\begin{array}{c}\text { Sig. (2- } \\
\text { tailed) }\end{array}$}} \\
\hline & & \multirow{2}{*}{ Mean } & \multirow{2}{*}{$\begin{array}{c}\text { Std. } \\
\text { Deviation }\end{array}$} & \multirow{2}{*}{$\begin{array}{l}\text { Std. Error } \\
\text { Mean }\end{array}$} & \multicolumn{2}{|c|}{$\begin{array}{l}\text { 95\% Confidence Interval } \\
\text { of the Difference }\end{array}$} & & & \\
\hline & & & & & Lower & Upper & & & \\
\hline $\begin{array}{c}\text { Pair } \\
1\end{array}$ & $\begin{array}{l}\text { Skor Pretest } \\
\text { Skor Posttest }\end{array}$ & -2.290 & 2.807 & .504 & -3.320 & -1.261 & -4.543 & 30 & .000 \\
\hline
\end{tabular}

$H_{0}$ : media game digital edukatif kurang efektif digunakan untuk menulis laporan perjalanan siswa.

$H_{1}$ : media game digital edukatif efektif digunakan untuk menulis laporan perjalanan siswa.

$H_{0}$ diterima jika t hitung $<\mathrm{t}$ tabel;

$t$ tabel ${ }_{(30 ; 0,05)}$ adalah 1,697
Nilai t hitung $(4,543)>\mathrm{t}$ tabel $(30 ; 0,05)$ adalah 1,697, maka Ho ditolak. Jadi hasil menulis laporan perjalanan siswa peningkatannya signifikan.

\section{SIMPULAN}

Berdasarkan hasil penelitian dan pembahasan dapat diperoleh simpulan sebagai berikut. (1) berdasarkan analisis kebutuhan dari hasil 
observasi, wawancara, dan angket menunjukkan bahwa menulis merupakan salah satu kompetensi yang cukup sulit dikembangkan, Selain itu, media yang digunakan guru masih konvensional dan tidak bervariasi; (2) desain game digital edukatif dirancang berdasarkan tahapan pembuatan analisis game sejenis, pembuatan story board, pembuatan flowchart view, dan pengumpulan bahan; (3) media game digital edukatif yang telah dikembangkan termasuk dalam kategori sangat baik berdasarkan validasi ahli materi. Validasi ahli materi ini meliputi aspek format, aspek isi, aspek bahasa, dan aspek pembelajaran. Hasil rata-rata validasi ahli materi yaitu 4,67. Validasi ahli media termasuk dalam kategori baik, dilakukan sebanyak dua kali. Validasi pertama memperoleh hasil rata-rata $\mathbf{4 , 0 5}$, sedangkan validasi kedua yaitu 4,21. Validasi ahli media ini meliputi aspek tampilan dan aspek pemprograman. Oleh karena itu, media game digital edukatif yang dikembangkan ini layak digunakan untuk pembelajaran menulis laporan perjalanan siswa SMP; (4) pada saat uji coba lapangan, siswa terlihat antusias dalam mengikuti pembelajaran menulis laporan perjalanan dengan menggunakan media game digital edukatif, (a) pada uji coba satu-satu terdapat beberapa masukan dari siswa untuk perbaikan media ini yaitu petunjuk bermain pada media game digital yang dikembangkan perlu diperjelas, backsound pada game tidak terlalu terdengar meskipun volume suara sudah penuh, dan pada kolom isian, perlu ditambahkan petunjuk mengenai langkah yang harus dikerjakan siswa. rintangan pada tiap tahap game perlu diberi variasi karena siswa tidak mengalamai kesulitan dalam menyelesaikan setiap tahap. Validasi pada uji coba memperoleh hasil rata-rata hasil rata-rata 3,80, sehingga mendapat kriteria baik, (b) pada uji coba kelompok kecil mendapat masukan bahwa game digital edukatif ini perlu diberi judul agar siswa mengerti tujuan dari game. Pada uji coba kelompok kecil ini, siswa sudah dapat bermain dengan lancar karena petunjuk bermain telah dikuasai dengan baik. Rintangan game pada uji coba kelompok kecil ini sudah ditingkatkan. Uji coba kelompok kecil pada lima orang siswa mendapat hasil rata-rata 4,22. Oleh karena itu, hasil uji kelompok kecil pada penelitian ini mendapat kriteria sangat baik, (c) Pada uji coba kelompok besar, siswa tidak mengalami kesulitan dalam hal petunjuk bermain. Siswa mengikuti setiap tahap dalam game. Petunjuk dan soal dalam game diikuti dengan baik, sehingga siswa tidak mengalami kesulitan dalam menuangkan ide karangan pada kolom yang telah disediakan. Pada uji coba lapangan ini mendapat hasil rata-rata 3,90, sehingga media game digital edukatif ini mendapat kriteria baik, (d) berdasarkan uji keefektifan, terdapat perbedaan yang signifikan antara hasil menulis laporan perjalanan siswa antara sebelum dengan sesudah menggunakan media game digital edukatif.

\section{DAFTAR PUSTAKA}

Fauzi, A. (2012). Strategi menulis laporan perjalanan, artikel. Diunduh pada tang-gal 8 Mei 2013, dari http://bermututigaputri.guru-indonesia.net.

Sadiman, A. S. (2010). Media pendidikan. Jakarta: PT Raja Grafindo Persada.

Borg, W. R. \& Gall, M.D. (1983). Educational research an introduction $\left(4^{\text {th }} \mathrm{ed}\right)$. New York \& London: Longman.

Nurgiyantoro, B. (2011). Penilaian pembelajaran bahasa berbasis kompetensi. Yogyakarta: BPFE.

Widoyoko, E. P. (2009). Evaluasi program pembelajaran. Yogyakarta: Pustaka Pelajar.

Prensky, M. (2001). The digital game-based learning revolution. New York: McGraw-Hill.

Rieber, L. P. (1996). Seriously considering play: designing interactive learning environments based on the blending of microworlds, simulations, and games. Educational Technology Research \& Development, 44 (2), 43-58.

Sandford, R. \& Williamson B. (2005). Games and learning. A handbook from NESTA Futurelab.

Teed, R. (2010). Games-based learning. Diunduh pada tanggal 26 Juli 2012, dari http://serc.carleton.edu/introgeo/games/i ndex.html.

Torrente, J., Eugenio J.M., Angel D.B. (2009). Production of creative game-based learning scenarios. A handbook for Teachers. Education and Culture DG: Lifelong Learning Programme.

Van Eck, R. (2006). Digital game-based learning. Educause Review, vol. 41, no. 2 (March/April 2006): 16-30. Diunduh pada tanggal 8 Mei 2013, dari http://www.educause.edu/ero/article/dig ital-game-based-learning. 